\title{
REACTION OF Melipona rufiventris LEPELETIER TO CITRAL AND AGAINST AN ATTACK BY THE CLEPTOBIOTIC BEE Lestrimelitta limao (SMITH) (HYMENOPTERA: APIDAE: MELIPONINA)
}

\author{
POMPEU, M. S. and SILVEIRA, F. A. \\ Laboratório de Sistemática e Ecologia de Abelhas, Departamento de Zoologia, Instituto de Ciências \\ Biológicas, UFMG, C.P. 486, CEP 30123-970, Belo Horizonte, Minas Gerais, Brazil \\ Correspondence to: Maurício dos Santos Pompeu, Laboratório de Sistemática e Ecologia de Abelhas, \\ Departamento de Zoologia, ICB/UFMG, C.P. 486, CEP 30123-970, Belo Horizonte, MG, \\ e-mail: mauriciopomp@hotmail.com \\ Received May 27, 2003 - Accepted October 15, 2003 - Distributed February 28, 2005
}

(With 1 figure)

Cleptobiotic (robber) bees have their own nests but steal food from nests of other species, instead of collecting it from flowers (Michener, 1974). One genus of cleptobiotic Meliponina, Lestrimelitta Friese, occurs in the neotropical region (Michener, 2000) and is represented in Brazil by at least four species (Camargo \& Moure, 1990).

Raids by Lestrimelitta limao against nests of other bees were described in detail by Sakagami \& Laroca (1963) and Sakagami et al. (1993). Workers of this species plunder pollen and honey provisions and other material such as resins and cerumen from colonies of other meliponine bees and even of Apis mellifera (Michener, 1974). The attacks by these robber bees weaken and even eliminate colonies, due to foodstock exhaustion and death of adults and larvae. During their raids, L. limao workers release an alarm pheromone mainly composed of citral, which is responsible for disrupting the defensive organization inside the attacked colony (Blum et al., 1970). It is believed that species not susceptible to social disruption by citral are rarely, if ever, attacked by Lestrimelitta (Michener, 1974). One of these species is Melipona rufiventris, which up to now has not been known to react to the presence of citral nor to be raided by L. limao (Blum et al., 1970). However, the direct observation of an unsuccessful attack by L. limao on a colony of M. rufiventris and indirect evidence of successful attacks on other colonies of the same species led us to reevaluate the reaction of $M$. rufiventris to citral and to compare it to the reaction exhibited by M. quadrifasciata (a known prey of L. limao).
To compare the reaction to citral of $M$. quadrifasciata with that of $M$. rufiventris, the rate of bees leaving four populous colonies of each species was measured under three treatments. In the first, workers leaving the nests under no artificial stimulus were counted; in the second, bees were counted after clean cotton wadding was introduced through the nest entrance; and in the third treatment counting was done after introducing cotton wadding soaked with citral. All countings were done during three-minute intervals, and performed in sequence for each colony. Experiments with M. rufiventris were carried out on January 15, 2003, in the municipality of Brasilândia de Minas where colonies of this species were located in a meliponine bee yard inside a reserve of cerrado (Brazilian savanna) at Fazenda Brejão (17 $00^{\prime} \mathrm{S}, 45^{\circ} 54^{\prime} \mathrm{W}$, and $440 \mathrm{~m}$ above sea level). Tests involving $M$. quadrifasciata were performed on April 7, 2003, in the municipality of Sabará. Colonies of this species were located in the backyard of a residence on the edge of the town's urban area (19.54'00'S, $43^{\circ} 47^{\prime} 04^{\prime \prime} \mathrm{W}$; and $800 \mathrm{~m}$ above sea level). Both places are in the State of Minas Gerais, Brazil. The citral employed is commercially produced by Georges Broemme Aromas e Fragrâncias Ltda., São Paulo, Brazil. Mean rates were compared by ANOVA after the normality and homogeneity of variances were tested.

The results confirmed those obtained by Blum et al. (1970). Individuals of the M. quadrifasciata colonies reacted to the presence of citral by leaving their nests in dramatically increasing numbers $\left(\mathrm{F}_{(2,9)}=\right.$ 7.87; $\mathrm{p}<0.01$, Fig. 1a), while no increase was recorded for $M$. rufiventris $\left(\mathrm{F}_{(2.9)}=0.98 ; \mathrm{p}=0.41\right.$, Fig. 1b). In fact, a non-significant trend towards a reduction in the 
number of bees leaving their nests was observed for M. rufiventris following introduction of the stimulus (Fig. 1b). Moreover, after citral was introduced, a strong buzzing was heard inside the colonies of $M$. rufiventris.

The reaction of a colony of $M$. rufiventris to a true attack by $L$. limao, however, was quite different. This was observed at $8 \mathrm{~h}\left(24^{\circ} \mathrm{C}\right.$ and $72 \%$ relative humidity) on January 8, 2002, in the same bee yard where the experiments described above were made with $M$. rufiventris. The raid started with the arrival of a group of $L$. limao workers (estimated as comprising at least 100 bees). The robbers flew at the side of a hive of $M$. rufiventris for about a minute, after which they started to hover in front of the nest entrance.
Suddenly about 10 bees flew to the entrance hole, five of which managed to enter the nest. The others were immediately chased by $M$. rufiventris that were at the entrance. Innumerous workers of the attacked colony left the nest and started to guard the entrance, while others agitatedly walked on the external walls of the hive. In the meantime many other bees left the nest to directly attack the $L$. limao still flying nearby. In only 30 seconds, the attacking group was dispersed, with only a few robber bees remaining; these were fighting the defending bees on the soil under the nest. The nest was observed for the rest of the day and for the following two, and no other attack, nor even a sign thereof, was again registered in this colony.
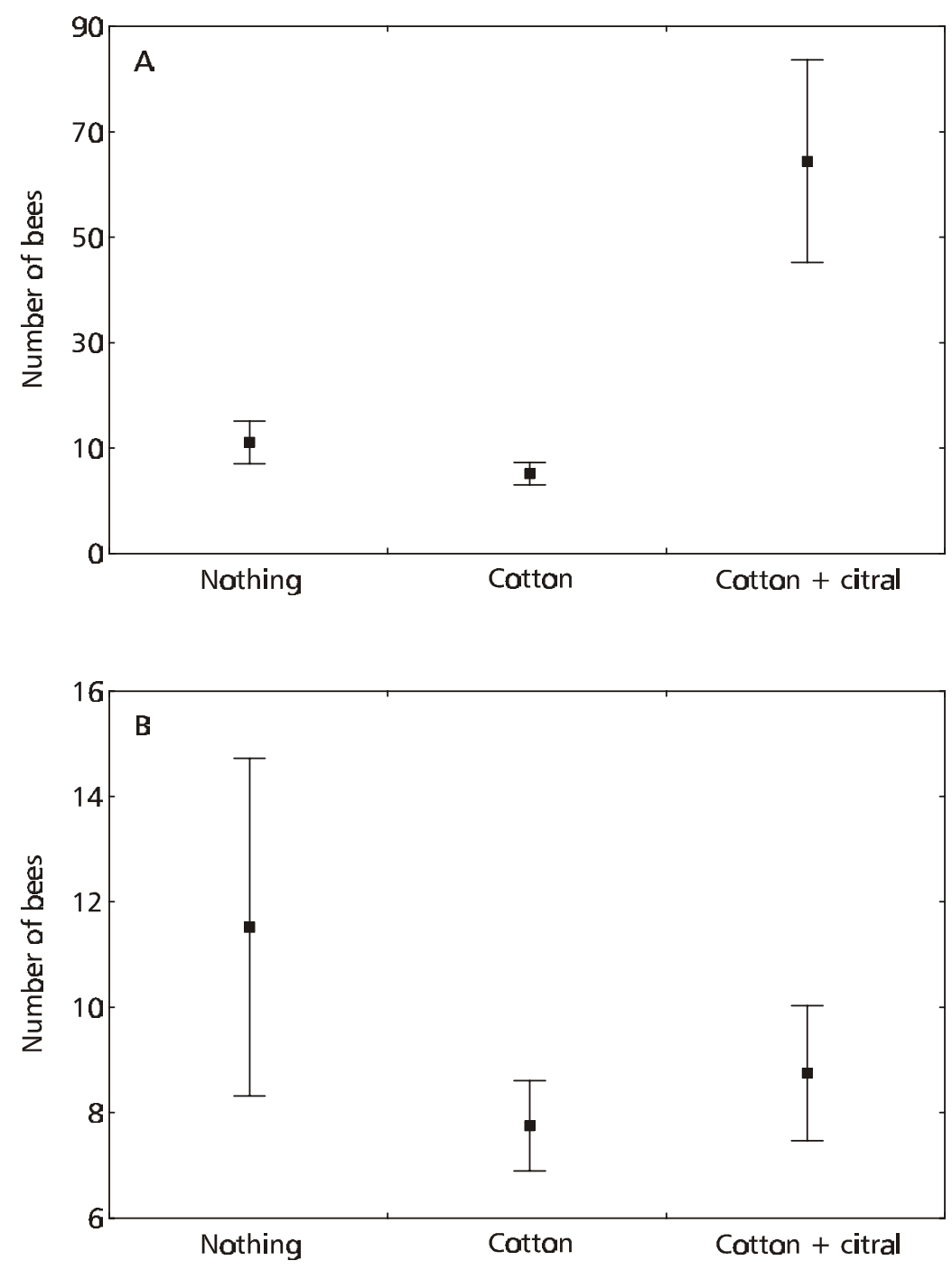

Fig. 1 - Mean number of workers of (A) Melipona quadrifasciata and (B) Melipona rufiventris ( \pm standard error) leaving the nest during 3 minutes before any stimulus (nothing); after introduction of clean cotton wadding into the entrance hole (cotton), and after introduction of cotton wadding soaked with citral (cotton + citral). Measurements were taken in four colonies. 
Ability to efficiently deter attacks by $L$. limao on species of Melipona was reported also for $M$. bicolor Lepeletier by Lucas de Oliveira (referred to by Sakagami \& Laroca, 1963, as M. nigra Lepeletier). However, none of these authors gave any details on the defensive behavior of this species.

It should be noted that the nest observed was relatively populous, numbering about 200 foragers at that time (colony " $\mathrm{A}$ ", in Pompeu, 2003). But there is evidence indicating that weak colonies of $M$. rufiventris may be susceptible to raids by L. limao. In the same bee yard at Fazenda Brejão, two other colonies considerably less populous than the preceding one presented sudden weakness in August, 2002 , and eventually died. Their adult population was reduced to about 10 workers and the queen, and all the stored food was exhausted between two inspections about 30 days apart. No young larvae were left, only remains of cells apparently torn by mandible action and mere traces of food were found. These are all signs described by Nogueira-Neto (1970) as characteristic of meliponine nests attacked by L. limao. Since other six colonies of $M$. rufiventris in the same bee yard stored honey and pollen during that period, shortage of food was probably not the cause of such drastic weakening of the other two colonies.

The observations above suggest that populous colonies of $M$. rufiventris are able to defend themselves against raids by $L$. limao. They also support the idea of Blum et al. (1970) and Michener (1974) that species not disturbed by citral would be relatively immune to the attacks by Lestrimelita. However, they also suggest that weak colonies of $M$. rufiventris may be successfully attacked and eventually destroyed by these robber bees.
Acknowledgements - V\&M Florestal Ltda. gave logistic and financial support to this project, which was partially financed by PROBIO. Biologist Roderic B. Martines allowed us the use of his colonies of M. quadrifasciata in our experiments.

\section{REFERENCES}

BLUM, M. S., CREWE, R. M., KERR, W. E., KEITH L. E., GARRISON, A. W. \& WALKER, M. M., 1970, Citral in stingless bees: isolation and functions in trail-laying and robbing. J. Insect Physiol., 16: 1637-1648.

CAMARGO, J. M. F. \& MOURE, J. S., 1989 (1990), Duas espécies novas de Lestrimelitta Friese (Meliponinae, Apidae, Hymenoptera) da região amazônica. Bol. Mus. Para. Emílio Goeldi, série Zoologia, 5: 195-212.

MICHENER, C. D., 1974, The social behavior of bees. A comparative study. Belknap, Cambridge, xii $+404 \mathrm{p}$.

MICHENER, C. D., 2000, The bees of the world. Johns Hopkins University, Baltimore, 913p.

NOGUEIRA-NETO, P., 1970, A criação racional de abelhas indigenas sem ferrão. $2^{2}$ ed. Tecnapis, São Paulo, 356p.

POMPEU, M. S., 2003, Aspectos bionômicos de Melipona rufiventris (Hymenoptera: Meliponina) e sugestões para sua conservação. M.S. Dissertation, Universidade Federal de Minas Gerais, Belo Horizonte, 119p.

SAKAGAMI, S. F. \& LAROCA, S., 1963, Additional observations on the habits of the cleptobiotic stingless bees, the Genus Lestrimelitta Friese (Hymenoptera, Apoidea). J. Fac. Sci., Hokkaido University, series VI, Zoology, 15: 319-339.

SAKAGAMI, S. F., ROUBIK, D. W. \& ZUCCHI, R., 1993, Ethology of the robber stingless bee, Lestrimelitta limao (Hymenoptera, Apidae). Sociobiology, 21: 237-277. 